\title{
A Study on the Status of Radiation Safety Management Knowledge, Attitude, and Behavior of Radiation Workers in Dental Institutions
}

\author{
Cheon-Hee Lee ${ }^{1}$, Seung Hui Choi ${ }^{2}$ \\ Department of Dental Hygiene, ${ }^{1}$ Andong Science College, ${ }^{2}$ Catolic Sangji College, Andong, Korea
}

Objective: The purpose of this study is to investigate the characteristics of knowledge, attitude, behavior, and dental radiography disinfection for dental hygienists who work mostly in radiography at dental institutions. It is intended to provide evidence to improve the level of radiation safety management behavior of dental institutions.

Methods: The subjects of this study were randomly selected medical institutions in general hospitals, dental hospitals, and dental clinics, and those who understood the purpose of this study and agreed in writing to participate in the study. Of the total 151 questionnaires, 142 were used for the final analysis, excluding 9 inappropriate questionnaires.

Results: Radiation safety management knowledge is, the highest at $3.58 \pm 1.035$ was that the occupational exposure dose regulation could not exceed an average of $20 \mathrm{mSv}$ per year for 5 years, the lowest was found to be $1.56 \pm 0.869$ after being able to measure personal exposure with thermoluminescent dosimeter (TLD) badge or film badge, the radiation safety management attitude is as follow. The highest score of $3.27 \pm 1.266$ was that the radiation defense apron was kept unbent or folded, the lowest was $1.42 \pm 0.702$ indicating that the menstrual cycle or pregnancy of infertile women should be checked before irradiation.

Conclusion: As a result of the above, it is suggested to provide regular education programs to dental radiation workers so that they can practice them in medical institutions by raising awareness of the knowledge, attitude, and behavior of radiation safety management.

Keywords: radiation workers, protection, radiation safety management

\section{Introduction}

With the development of modern science and technology,

\section{Corresponding author Seung Hui Choi}

E-mail: chsh3918@csj.ac.kr

(iD) https://orcid.org/0000-0002-5967-1875

Received December 3, 2021, Revised December 20, 2021 , Accepted December 20, 2021 oral imaging is in the stage of utilizing molecular images as well as image signals of changes in anatomy [1]. Medical radiation is used for diagnosis, treatment, and research of human diseases to protect health from diseases and advance medicine has played an important role in making [2]. With the development of medical technology, not only the use of radiation devices for diagnosis and treatment increases, but also as the public's awareness of dental care increases, oral radiography continues to increase [3]. In most dental medical institutions, not only intraoral radiographs, but also extraoral radiographs

Copyright (C) 2021. Korean Academy of Preventive Dentistry.

This is an Open Access article distributed under the terms of the Creative Commons Attribution Non-Commercial License (http://creativecommons.org/licenses/ by-nc/4.0) which permits unrestricted non-commercial use, distribution, and reproduction in any medium, provided the original work is properly cited. 
and panoramic radiographs are used in various oral and maxillofacial areas such as the treatment of carious teeth and periodontal disease, diagnosis of temporomandibular joint disorders and malocclusion, and implant placement [4]. Recently, as the treatment of radiation increases in the medical field, interest in radiation safety and risk is increasing. Although it is known that the amount of radiation used in dentistry is very small and does not cause any major problems to the human body [5], the radiation used in dentistry is low dose. It has been reported that long-term exposure can cause physical disorders such as hair loss, erythema, ulcers, infertility, and chronic dermatitis, and increase the risk of leukemia as well as genetic effects [6]. Anyone who handles radiation is interested in radiation safety management, but there are cases where people are exposed to radiation more than necessary due to a lack of knowledge, self-confidence in handling radiation, and underestimation of radiation risks. In some cases, it is not known whether or not the person has been exposed [7]. To prevent damage from radiation exposure, the International on Radiological Protection (ICRP) recommended a dose limit of $20 \mathrm{mSv}$ per year (5 years average) for radiation-related workers and less than $1 \mathrm{mSv}$ for the general public [8], article 37 of the Medical Act According to Paragraph 2, when the founder or manager of a medical institution installs a radiation generating device for diagnosis, as prescribed by Ordinance of the Ministry of Health and Welfare, a person in charge of safety management of radiation for diagnosis (hereinafter referred to as 'safety management manager') shall be appointed, and shall undergo regular examination and measurement, it is recorded [9]. At present, dental hygienists in dental medical institutions can perform preventive treatment and medical assistant work under the supervision of a dentist. In accordance with Article 37 (1) of the Medical Act, it is stipulated that dental hygienists can perform intraoral diagnostic radiography at health or medical institutions that have installed a diagnostic radiation generator in accordance with safety management standards, most of the practitioners in charge of radiography and management in dental medical institutions were found to be dental hygienists [10]. Dental hygienists, including dental hygienists in charge of dental radiography, are not receiving adequate radiation safety management education or exposure management. Yun [11] said that there was no difference in the study of knowledge, attitude, and practice, and that radiation safety management education was insufficient. There is insufficient education on radiation safety management for dental radiation workers. The purpose of this study is to investigate the knowledge, attitude, behavior, and characteristics of dental radiography disinfection on radiation safety management for dental hygienists who are mostly engaged in radiography at dental medical institutions, and to improve the level of radiation safety management behavior in dental medical institutions. We want to provide you with the evidence to support this.

\section{Materials and Methods}

\section{Study design}

This study investigates the knowledge, attitude, behavior, and disinfection of dental radiography on radiation safety management for dental hygienists who are mostly engaged in radiography at dental medical institutions.

\section{Subjects}

The subjects of this study are those who understand the purpose of this study and consent in writing to participate in dental hygienists who are currently working in dentistry by arbitrarily selecting medical institutions of general hospitals, dental hospitals, and dental clinics. The survey was conducted from March to September 2021. Of the total 151 questionnaires distributed, 142 questionnaires were used for the final analysis, excluding 9 inappropriate questionnaires.

\section{Data analysis}

In this study, the statistical package used for statistical analysis was analyzed with PASW Statistics for Window ver. 18.0 (IBM Co., Armonk, NY, USA) program.

1) The general characteristics of subjects were analyzed using frequency and percentage.

2) The characteristics of dental radiation safety management knowledge were analyzed using frequency analysis and t-test.

3) The characteristics of dental radiation safety management attitude were analyzed using frequency analysis and t-test.

4) The characteristics of dental radiation safety management behavior were analyzed using frequency analysis and t-test.

5) Disinfection of dental radiography equipment was analyzed using frequency analysis.

6) The practice of infection control in the dental radiography room was analyzed using the frequency analysis.

\section{Results}

\section{General characteristics of subjects}

Looking at the general characteristics of the subjects of this study, 44 people (29.1\%) aged $20-25,39$ people $(25.8 \%)$ aged $26-30,40$ people $(26.5 \%)$ aged $31-33,9$ people $(6.0 \%)$ aged $36-40$, and those over 41 years old were 10 people $(6.6 \%)$. By sex, 125 people $(82.8 \%)$ were female, and the workplaces 
Table 1. General characteristics of subjects $(N=142)$

\begin{tabular}{|c|c|c|}
\hline \multicolumn{2}{|c|}{ Item } & \multirow{2}{*}{$\begin{array}{l}\text { Group } \\
44(29.1)\end{array}$} \\
\hline Age & $20-25$ & \\
\hline & $26-30$ & $39(25.8)$ \\
\hline & $31-35$ & $40(26.5)$ \\
\hline & $36-40$ & $9(6.0)$ \\
\hline & 41 & $10(6.6)$ \\
\hline \multirow[t]{2}{*}{ Sex } & Male & $17(11.3)$ \\
\hline & Female & $125(82.8)$ \\
\hline \multirow[t]{4}{*}{ Place of work } & General/university hospital & $14(9.3)$ \\
\hline & Dental hospital & $14(9.3)$ \\
\hline & Dental clinic & $112(74.2)$ \\
\hline & Public health center & $2(0.3)$ \\
\hline \multirow[t]{5}{*}{ Years of service } & $>1$ & 33 (21.9) \\
\hline & $1-5$ & $16(10.6)$ \\
\hline & 6-10 & $21(13.9)$ \\
\hline & $11-15$ & $56(37.1)$ \\
\hline & 16 & $16(10.6)$ \\
\hline \multirow{4}{*}{$\begin{array}{l}\text { Possession of intraoral } \\
\text { radiography equipment }\end{array}$} & 1 & $116(76.8)$ \\
\hline & 2 & $17(11.3)$ \\
\hline & 3 & $8(5.3)$ \\
\hline & None & $1(7.0)$ \\
\hline \multirow{3}{*}{$\begin{array}{l}\text { Possession of extraoral } \\
\text { radiography equipment }\end{array}$} & 1 & $116(76.8)$ \\
\hline & 2 & $14(9.3)$ \\
\hline & None & $12(7.9)$ \\
\hline \multirow{5}{*}{$\begin{array}{l}\text { Whether the defense } \\
\text { facility is safe }\end{array}$} & Very well done & $79(52.3)$ \\
\hline & Well done & $45(29.8)$ \\
\hline & Average & $13(8.6)$ \\
\hline & It's not going well & $5(3.3)$ \\
\hline & Not done at all & $0(0.0)$ \\
\hline \multirow{6}{*}{$\begin{array}{l}\text { Defense equipment } \\
\text { (multiple responses) }\end{array}$} & Defense wall (lead wall) & $138(91.4)$ \\
\hline & Protective partition & $98(64.9)$ \\
\hline & Lead apron & $102(76.5)$ \\
\hline & Neck protection & $114(75.5)$ \\
\hline & Lead gloves & $14(9.3)$ \\
\hline & etc. & $70(46.4)$ \\
\hline \multirow{2}{*}{$\begin{array}{l}\text { Safety management } \\
\text { training }\end{array}$} & Yes & $137(90.7)$ \\
\hline & No & $5(3.3)$ \\
\hline Total & & $142(100.0)$ \\
\hline
\end{tabular}

Values are presented as number (\%).

were general and university hospitals with 14 people $(9.3 \%)$, dental hospitals with 14 people $(9.3 \%)$, dental clinics with 112 people (74.2\%), and public health centers with 2 people $(0.3 \%)$. As for the number of years of service, those with less than 1 year and those who worked for 11 to 15 years had the highest number of 56 people (37.1\%). 116 people $(76.8 \%$ ) had the highest number of internal and external radiographers, each having one. The safety of the defense facilities was very good, with 79 people $(52.3 \%)$ showing the highest level, and as defense equipment, the defensive wall was the highest at 138 people (91.4\%), neck covering was found in 114 people $(75.5 \%)$, followed by lead apron in 102 people (76.5\%). 137 people (90.7\%) had safety management education or not (Table 1).

\section{Dental radiation safety management knowledge}

Looking at the knowledge of dental radiation safety management, 'occupational exposure dose regulations cannot exceed $20 \mathrm{mSv}$ per year on average for 5 years' is $3.58 \pm 1.035$, and 'if the distance between focus-films increases, skin exposure decreases' is $3.20 \pm 1.098$. 'Extraoral radiography has a higher radiation dose than intraoral radiography' is $1.67 \pm 1.045$, and 'thermoluminescent dosimeter (TLD) or film badge can measure individual radiation dose' is $1.56 \pm 0.869$ (Table 2).

\section{Dental radiation safety management attitude}

When looking at the dental radiation safety management attitude, 'The apron for radiation protection should not be bent or folded' was found to be the highest at $3.27 \pm 1.266$, and 'to protect the gonad and thyroid gland when irradiating to children, protective equipment should be used' was $2.98 \pm 1.227$, 'X-ray dose should be adjusted according to conditions such as the patient's age, area to be photographed, and film type' was $1.45 \pm 0.810$, and 'The menstruation of women of childbearing age before radiation exposure, period or pregnancy should be checked' was $1.42 \pm 0.702$ (Table 3 ).

\section{Dental radiation safety management behavior}

Regarding dental radiation safety management behavior, the highest score was $3.68 \pm 1.078$ when performing or receiving a performance test of an apron for radiation protection, and the second highest was maintained at an appropriate distance from the radiation source and the patient during irradiation was $3.17 \pm 1.201$. The lowest value was $1.74 \pm 1.182$, when the protector wore protective clothing as an assistant for positioning the patient during radiation irradiation, and $1.59 \pm 0.915$ after adjusting the X-ray dose according to conditions such as age, area to be photographed, and film size (Table 4).

\section{Disinfection of dental radiography equipment}

When looking at the disinfection of dental radiography equipment, 50 people $(33.1 \%)$ disinfect the X-ray tube head once a month, the digital sensor disinfection once a day 63 people (41.7\%), and imaging aids (XCP-Universal Measurement and Calibration Protocol, etc.) once a day disinfection 55 people (36.4\%). Protective equipment (abductor, etc) disinfecting once a day 45 people $(29.8 \%)$, film cassette disinfection once a day 58 people $(38.4 \%)$, panoramic camera once a day disinfection 58 people (38.4\%), disinfecting the cephalopod once a day 55 people (36.4\%), and disinfecting the back seat and stool for each patient 52 people (34.4\%) (Table 5). 
Table 2. Dental radiation safety management knowledge $(\mathrm{N}=142)$

\begin{tabular}{|c|c|c|c|c|c|c|}
\hline Item & Very & Yes & Average & Not like that & Very not & $M \pm S D$ \\
\hline The intensity of X-rays decreases as the distance increases. & $29(19.2)$ & $72(47.7)$ & $31(20.5)$ & $9(6.0)$ & $1(0.7)$ & $2.17 \pm 0.842$ \\
\hline $\begin{array}{l}\text { During X-ray exposure, neither the operator nor } \\
\text { the patient should hold the X-ray crown in their hands. }\end{array}$ & $41(27.2)$ & $55(36.4)$ & $36(23.8)$ & $6(4.0)$ & $4(2.6)$ & $2.12 \pm 0.981$ \\
\hline $\begin{array}{l}\text { Occupational exposure dose cannot exceed } 20 \mathrm{mSv} \text { per year, } \\
\text { averaged over the prescribed } 5 \text { years. }\end{array}$ & $3(2.0)$ & $21(13.9)$ & $35(23.2)$ & $55(36.4)$ & $28(18.5)$ & $3.58 \pm 1.035$ \\
\hline $\begin{array}{l}\text { There are } 2 \text { types of radiation damage: } \\
\text { chronic damage and rapid growth. }\end{array}$ & $26(17.2)$ & $78(51.7)$ & $27(17.9)$ & $11(7.3)$ & $0(0.0)$ & $2.17 \pm 0.813$ \\
\hline The gonads are very sensitive to radiation in the human body. & $33(21.8)$ & $62(41.1)$ & $34(22.5)$ & $13(8.6)$ & $0(0.0)$ & $2.21 \pm 0.897$ \\
\hline X-ray shielding is possible with lead or concrete materials. & 30 (19.9) & $50(33.1)$ & $41(27.2)$ & 19 (12.6) & $2(1.3)$ & $2.42 \pm 0.999$ \\
\hline $\begin{array}{l}\text { The switch for X-ray irradiation is installed outside the imaging } \\
\text { room and operated. }\end{array}$ & $44(29.1)$ & $63(41.7)$ & $28(18.5)$ & $6(4.0)$ & $1(0.7)$ & $2.01 \pm 0.864$ \\
\hline Radiation exposure can have a genetic effect. & 49 (32.5) & 66 (43.7) & 18 (11.9) & $6(4.0)$ & $3(2.0)$ & $1.94 \pm 0.915$ \\
\hline $\begin{array}{l}\text { In the safety management rules, the head of a medical } \\
\text { institution or the person in charge of safety management shall } \\
\text { require workers to receive regular health examinations at least } \\
\text { once a year. }\end{array}$ & $36(23.8)$ & $59(39.1)$ & $32(21.2)$ & $12(7.9)$ & $3(2.0)$ & $2.23 \pm 0.980$ \\
\hline Children are more sensitive to radiation than adults. & $59(39.1)$ & $37(24.5)$ & $31(20.5)$ & $10(6.6)$ & $5(3.3)$ & $2.07 \pm 1.114$ \\
\hline $\begin{array}{l}\text { As the focal-film distance increases, the amount of skin } \\
\text { exposure decreases. }\end{array}$ & $11(7.3)$ & $23(15.2)$ & $48(31.8)$ & $41(27.2)$ & $16(10.6)$ & $3.20 \pm 1.098$ \\
\hline Adjustment of the collimator directly affects the radiation dose. & $31(20.5)$ & $63(41.7)$ & $34(22.5)$ & $14(9.3)$ & $0(0.0)$ & $2.23 \pm 0.903$ \\
\hline $\begin{array}{l}\text { Extraoral radiography has a higher radiation dose than } \\
\text { intraoral radiography. }\end{array}$ & $91(60.3)$ & $25(6.6)$ & $12(7.9)$ & $12(7.9)$ & $2(1.3)$ & $1.67 \pm 1.045$ \\
\hline Individual exposure can be measured with a TLD or film badge. & $88(58.3)$ & $36(23.8)$ & $8(5.3)$ & $9(6.0)$ & $1(0.7)$ & $1.56 \pm 0.869$ \\
\hline Total & \multicolumn{6}{|c|}{$142(100.0)$} \\
\hline
\end{tabular}

Values are presented as number $(\%)$ or mean \pm standard deviation. $\mathrm{M}_{ \pm} \mathrm{SD}$ : mean \pm standard deviation, TLD: thermoluminescent dosimeter.

\section{Practices for infection control in dental radiography room}

Wearing gloves during dental radiography was the highest at 52 people (34.5\%), and 'I always wear a mask during dental radiography.' was 56 people $(37.1 \%)$, 'Sterilization or disinfection of film holding devices is sometimes worn.' was 68 people $(45.0 \%)$. As for the method of disinfection of dental radiography equipment, alcohol disinfection was the highest with 97 people (64.2\%), and 'Hang it in the studio' for storing the apron showed the highest with 87 people (57.6\%) (Table 6).

\section{Discussion}

The International Board of Broadcasting Service is doing medical service, and it is exploding as medical service and technology advance while doing medical service [12]. In dental medical institutions, the proportion of not only intraoral radiography, but also extraoral radiography and digital radiography is increasing. The purpose of this study is to identify the knowledge, attitude, behavior and characteristics of dental radiography disinfection on radiation safety management for dental hygienists who are most engaged in radiography at dental medical institutions. As for the age of the subjects of this study, 44 people $(29.1 \%)$ were aged $20-25,39$ people $(25.8 \%)$ were aged 26-30, and 40 people (26.5\%) were aged 31-33. By sex, 125 people $(82.8 \%)$ were female, and the highest number of workplaces was a dental clinic with 112 people (74.2\%). As for the number of years of service, 11-15 years old were the highest with 56 people (37.1\%), and 116 people (76.8\%) of each had one internal/external radiographer. The safety of the defense facilities was very good, with 79 people (52.3\%) showing the highest level, and for defense equipment, the defensive wall was the highest at $138(91.4 \%)$, with a neck covering 114 people $(75.5 \%)$, and a lead apron 102 people $(76.5 \%)$. In the results of this study, 137 people (90.7\%) had safety management education, but in $\mathrm{Kim}$ [13]'s study, it was reported that $83.0 \%$ of the total and $84.3 \%$ of radiologists received radiation safety management training. In a study conducted by Han [7], 71.0\% of radiation workers in medical institutions received education. Compared with the results of the study, the level of radiation safety management education in dental medical institutions was low.

The reason for the high results of this study is that students 
Table 3. Dental radiation safety management attitude $(\mathrm{N}=142)$

\begin{tabular}{|c|c|c|c|c|c|c|}
\hline Item & Very & Yes & Average & Not like that & Very not & $M \pm S D$ \\
\hline $\begin{array}{l}\text { Dosimetry for dosimetry of radiation equipment } \\
\text { should be performed regularly. }\end{array}$ & $40(26.5)$ & $74(49.0)$ & 27 (17.9) & $0(0.0)$ & $1(0.7)$ & $1.94 \pm 0.724$ \\
\hline $\begin{array}{l}\text { The performance test of the apron for radiation protection } \\
\text { must be tested or received. }\end{array}$ & $42(27.8)$ & $54(35.8)$ & $38(25.2)$ & $6(4.0)$ & $2(1.3)$ & $2.09 \pm 0.928$ \\
\hline $\begin{array}{l}\text { It is good to keep the apron for radiation protection } \\
\text { not to be bent or folded. }\end{array}$ & $17(11.3)$ & $23(15.2)$ & $29(19.2)$ & 49 (32.5) & $24(15.9)$ & $3.27 \pm 1.266$ \\
\hline $\begin{array}{l}\text { A legal dosimeter must be worn at all times } \\
\text { during weightless conditions. }\end{array}$ & $36(23.8)$ & $67(44.4)$ & $34(22.5)$ & $5(3.3)$ & $0(0.0)$ & $2.06 \pm 0.796$ \\
\hline $\begin{array}{l}\text { Individual radiation dose values should be measured } \\
\text { monthly or quarterly. }\end{array}$ & $32(21.2)$ & $63(41.7)$ & $32(21.2)$ & $15(9.9)$ & $0(0.0)$ & $2.23 \pm 0.911$ \\
\hline $\begin{array}{l}\text { It is recommended to receive regular training on } \\
\text { radiation safety management. }\end{array}$ & 39 (25.8) & $52(34.4)$ & $37(24.5)$ & $13(8.6)$ & $1(0.7)$ & $2.22 \pm 0.961$ \\
\hline $\begin{array}{l}\text { In relation to radiation exposure, regular medical examinations } \\
\text { should be performed. }\end{array}$ & $53(35.1)$ & $56(37.1)$ & 28 (18.5) & $4(2.6)$ & $1(0.7)$ & $1.91 \pm 0.864$ \\
\hline $\begin{array}{l}\text { When irradiating radiation, work must be done } \\
\text { behind the barrier (plate). }\end{array}$ & $57(37.7)$ & $56(37.1)$ & $20(13.2)$ & $6(4.0)$ & $3(2.0)$ & $1.90 \pm 0.950$ \\
\hline $\begin{array}{l}\text { Protective clothing must be worn when working in } \\
\text { the irradiated area. }\end{array}$ & $43(28.5)$ & $53(35.1)$ & 31 (20.5) & $12(7.9)$ & $3(2.0)$ & $2.17 \pm 1.014$ \\
\hline $\begin{array}{l}\text { During irradiation, an appropriate distance between } \\
\text { the radiologist and the patient should be maintained. }\end{array}$ & $64(42.4)$ & $40(26.5)$ & 27 (17.9) & $6(4.0)$ & $5(3.3)$ & $1.95 \pm 1.065$ \\
\hline $\begin{array}{l}\text { When irradiating children, protective equipment } \\
\text { should be used to shield the gonads and thyroid gland. }\end{array}$ & $26(17.2)$ & $20(13.2)$ & $40(26.5)$ & 37 (24.5) & $16(10.6)$ & $2.98 \pm 1.277$ \\
\hline $\begin{array}{l}\text { Protective clothing should be worn by the guardian } \\
\text { as an assistant in positioning the patient during irradiation. }\end{array}$ & $41(27.2)$ & $64(42.4)$ & 27 (17.9) & $10(6.6)$ & $0(0.0)$ & $2.05 \pm 0.879$ \\
\hline $\begin{array}{l}\text { The amount of X-ray irradiation should be adjusted } \\
\text { according to the patient's age, the area to be photographed, } \\
\text { and the type of film. }\end{array}$ & $100(66.2)$ & $26(17.2)$ & $13(8.6)$ & $1(0.7)$ & $2(1.3)$ & $1.45 \pm 0.810$ \\
\hline $\begin{array}{l}\text { Before irradiation, the menstrual cycle or pregnancy status of } \\
\text { women of childbearing potential should be checked. }\end{array}$ & 95 (62.9) & $35(23.2)$ & $8(5.3)$ & $3(2.0)$ & $1(0.7)$ & $1.42 \pm 0.702$ \\
\hline $\begin{array}{l}\text { Radiation should be shielded according to the menstrual cycle } \\
\text { or pregnancy status of women of childbearing potential. }\end{array}$ & $45(29.8)$ & $67(44.4)$ & $29(19.2)$ & $0(0.0)$ & $1(0.7)$ & $1.91 \pm 0.758$ \\
\hline Total & \multicolumn{6}{|c|}{$142(100.0)$} \\
\hline
\end{tabular}

Values are presented as number $(\%)$ or mean \pm standard deviation. $\mathrm{M}_{ \pm} \mathrm{SD}$ : mean \pm standard deviation.

participated in radiation safety education as a required completion of radiation training classes at school, and the number of times of education was $65 \%$. Dental radiation safety management knowledge is shown in Table 2. 'Occupational exposure dose regulations cannot exceed $20 \mathrm{mSv}$ per year on average for 5 years' was the highest at $3.58 \pm 1.035$, and 'if the distance between focus-films increases, skin exposure decreases' is the second with $3.20 \pm 1.098$, appeared high as. According to a study by Park [14] and Ahn et al. [15], it is reported that a distance of at least $1.8 \mathrm{~m}$ and $2.0 \mathrm{~m}$ should be maintained. According to a study by Park and Lee [16], the distance between the tube head and the photographer of the X-ray camera was found to be $41.0 \%$ or less, and $36.0 \%$ for $1 \mathrm{~m}-1.5 \mathrm{~m}$ and $23.0 \%$ for the photographer. It appears that they are not keeping a safe distance. The lower value was $1.67 \pm 1.045$ for 'extraoral radiography has a higher radiation dose than intraoral radiography'. The advantages of digital radiation are that the radiation dose received by the patient is greatly reduced, the operator can see the X-ray image quickly, the characteristics of the X-ray photograph can be changed arbitrarily, the storage on the X-ray photograph is easy, and the film developer It is said to be environmentally friendly because it does not use [17]. In addition, the individual exposure dose could be measured with TLD or film badge, but it was found to be the lowest at 1.56 \pm .869 (Table 2).

According to Park [14]'s study, $43.8 \%$ of cases using film badges and $32.1 \%$ of dentists using TLD badges. Table 3 shows the attitude of dental radiation safety management. As for the radiation protection apron, it was the highest at $3.27 \pm 1.266$, indicating that it should not be bent or folded, and the second 
Table 4. Dental radiation safety management practices $(\mathrm{N}=142)$

\begin{tabular}{|c|c|c|c|c|c|c|}
\hline Item & Always & Usually & $\begin{array}{l}\text { Sometimes and } \\
\text { sometimes doesn't }\end{array}$ & $\begin{array}{l}\text { Usually it } \\
\text { doesn't }\end{array}$ & Not at all & $\mathrm{M} \pm \mathrm{SD}$ \\
\hline $\begin{array}{l}\text { Before use, check whether the radiation-related equipment } \\
\text { in the workplace is in a smooth working condition. }\end{array}$ & $35(23.2)$ & $57(37.7)$ & $39(25.8)$ & $7(4.6)$ & $4(2.6)$ & $2.20 \pm 0.972$ \\
\hline $\begin{array}{l}\text { Conduct or receive a performance test of } \\
\text { an apron for radiation protection. }\end{array}$ & $5(3.3)$ & $16(10.6)$ & $33(21.9)$ & $53(35.1)$ & $35(23.2)$ & $3.68 \pm 1.078$ \\
\hline $\begin{array}{l}\text { After using an apron for radiation protection, straighten it } \\
\text { and store it. }\end{array}$ & 25 (16.6) & $67(44.4)$ & $33(21.9)$ & $8(5.3)$ & $9(6.0)$ & $2.37 \pm 1.044$ \\
\hline $\begin{array}{l}\text { Wear a legal dosimeter at all times during } \\
\text { radiation-related work. }\end{array}$ & $28(18.5)$ & $55(36.4)$ & $39(25.8)$ & $14(9.3)$ & $6(4.0)$ & $2.42 \pm 1.042$ \\
\hline $\begin{array}{l}\text { I check the radiation exposure dose measured with } \\
\text { a personal dosimeter on a monthly or quarterly basis. }\end{array}$ & $28(18.5)$ & $45(29.8)$ & $46(30.5)$ & $16(10.6)$ & $7(4.6)$ & $2.53 \pm 1.072$ \\
\hline Regularly receive training on radiation safety management. & $35(23.2)$ & $56(37.1)$ & $34(22.5)$ & $10(6.6)$ & $7(4.6)$ & $2.30 \pm 1.068$ \\
\hline $\begin{array}{l}\text { Receive regular medical examinations in relation to } \\
\text { the confirmation of the effects of radiation exposure. }\end{array}$ & $41(27.2)$ & $58(38.4)$ & $25(16.6)$ & $9(6.0)$ & $9(6.0)$ & $2.22 \pm 1.123$ \\
\hline When irradiating, work behind the barrier (plate). & 33 (21.9) & $56(37.1)$ & $32(21.2)$ & $18(11.9)$ & $3(2.0)$ & $2.34 \pm 1.025$ \\
\hline Wear a protective suit when working in the irradiation area. & $55(36.4)$ & $31(20.5)$ & $34(22.5)$ & $9(6.0)$ & $13(8.6)$ & $2.28 \pm 1.286$ \\
\hline $\begin{array}{l}\text { When irradiating, keep an appropriate distance from } \\
\text { the radiation source and the patient. }\end{array}$ & $18(11.9)$ & $18(11.9)$ & $44(29.1)$ & $41(27.2)$ & 18 (11.9) & $3.17 \pm 1.201$ \\
\hline $\begin{array}{l}\text { When irradiating children, use protective gear to shield } \\
\text { the gonads and thyroid gland. }\end{array}$ & $33(21.9)$ & $58(38.4)$ & $31(20.5)$ & $12(7.9)$ & $8(5.3)$ & $2.34 \pm 1.100$ \\
\hline $\begin{array}{l}\text { Have the protector wear protective clothing as } \\
\text { an assistant for positioning the patient during irradiation. }\end{array}$ & $90(59.6)$ & $23(15.2)$ & $17(11.3)$ & $2(1.3)$ & $10(6.6)$ & $1.74 \pm 1.182$ \\
\hline $\begin{array}{l}\text { Adjust the X-ray dose according to conditions such as } \\
\text { age, area to be photographed, and film size. }\end{array}$ & $88(58.3)$ & $32(21.2)$ & $14(9.3)$ & $5(3.3)$ & $3(2.0)$ & $1.59 \pm 0.915$ \\
\hline $\begin{array}{l}\text { Check the menstrual cycle or pregnancy status of } \\
\text { women of childbearing potential before irradiation. }\end{array}$ & $38(25.2)$ & $66(43.7)$ & $29(19.2)$ & $4(2.6)$ & $5(3.3)$ & $2.11 \pm 0.946$ \\
\hline $\begin{array}{l}\text { When irradiating pregnant women, use a protective device } \\
\text { other than the area to be photographed. }\end{array}$ & $41(27.2)$ & $53(35.1)$ & $38(25.2)$ & $6(4.0)$ & $4(2.6)$ & $2.14 \pm 0.987$ \\
\hline Total & \multicolumn{6}{|c|}{$142(100.0)$} \\
\hline
\end{tabular}

Values are presented as number $(\%)$ or mean \pm standard deviation. $\mathrm{M} \pm \mathrm{SD}$ : mean \pm standard deviation.

Table 5. Disinfection of dental radiography equipment $(\mathrm{N}=142)$

\begin{tabular}{lccccc}
\hline \multicolumn{1}{c}{ Disinfection area } & For every patient & Once a day & Once a week & Once a month & Don't \\
\hline X-ray tube head & $9(6.0)$ & $21(13.9)$ & $29(19.2)$ & $50(33.1)$ & $33(21.9)$ \\
Digital sensor & $35(23.2)$ & $63(41.7)$ & $27(17.9)$ & $9(6.0)$ & $8(5.3)$ \\
Radiographic aids (XCP, etc.) & $26(17.2)$ & $55(36.4)$ & $35(23.2)$ & $17(11.3)$ & $9(6.0)$ \\
Defense equipment (lead skirt, etc.) & $24(15.9)$ & $45(29.8)$ & $41(27.2)$ & $15(9.9)$ & $17(11.3)$ \\
Film cassette & $38(25.2)$ & $58(38.4)$ & $26(17.2)$ & $8(5.3)$ & $12(7.9)$ \\
Panoramic camera & $41(27.2)$ & $58(38.4)$ & $23(15.2)$ & $12(7.9)$ & $8(5.3)$ \\
Cephalo camera & $28(18.5)$ & $55(36.4)$ & $32(21.2)$ & $16(10.6)$ & $11(7.3)$ \\
Back seat and stool & $52(34.4)$ & $48(31.8)$ & $25(16.6)$ & $8(5.3)$ & $9(6.0)$ \\
Total & & & $142(100.0)$ & & \\
\hline
\end{tabular}

Values are presented as number (\%). XCP: Universal Measurement and Calibration Protocol.

highest was $2.98 \pm 1.27$ that protective equipment should be used for shielding the gonads and thyroid gland when irradiating children with radiation. The lowest was 'X-ray dose should be adjusted according to conditions such as the patient's age, imaging site, and film type' was $1.45 \pm 0.810$, 'Before irradiation, it is necessary to check the menstrual cycle or pregnancy of women of childbearing potential' was $1.42 \pm 0.702$ (Table3). According to Park [14]'s study, $88.1 \%$ of cases without protective clothing wore protective clothing, $31.3 \%$ of pregnant women only wore protective clothing, and $16.4 \%$ of all pa- 
Table 6. Practices for infection control in dental radiography room $(N=142)$

\begin{tabular}{|c|c|c|c|c|}
\hline Item & Always & Occasionally & Not at all & etc. \\
\hline $\begin{array}{l}\text { Wearing gloves for dental } \\
\text { radiography }\end{array}$ & $31(20.5)$ & $16(10.5)$ & $52(34.5)$ & $40(26.5)$ \\
\hline $\begin{array}{l}\text { Wearing a mask during dental } \\
\text { radiography }\end{array}$ & $56(37.1)$ & $50(33.1)$ & $27(17.9)$ & $9(6.0)$ \\
\hline $\begin{array}{l}\text { Sterilization or disinfection of } \\
\text { the apron film holding device }\end{array}$ & $39(25.8)$ & $68(45.0)$ & $29(19.2)$ & $6(4.0)$ \\
\hline $\begin{array}{l}\text { How to disinfect dental } \\
\text { radiography equipment }\end{array}$ & $\begin{array}{l}\text { Alcohol disinfection } \\
\qquad 97(64.2)\end{array}$ & $\begin{array}{l}\text { Disinfectant for disinfection } \\
\qquad 19 \text { (12.6) }\end{array}$ & $\begin{array}{c}\text { Use a plastic cover } \\
17(11.3)\end{array}$ & $\begin{array}{l}\text { etc. } \\
9(5.9)\end{array}$ \\
\hline Apron storage & $\begin{array}{l}\text { I hung up the X-ray room } \\
\qquad 87(57.6)\end{array}$ & $\begin{array}{l}\text { Folded and equipped with X-ray room } \\
\qquad 25 \text { (16.6) }\end{array}$ & $\begin{array}{c}\text { Kept in the cabinet } \\
26(18.2)\end{array}$ & $\begin{array}{c}\text { No storage manual } \\
4(2.7)\end{array}$ \\
\hline Total & & $142(100.0)$ & & \\
\hline
\end{tabular}

Values are presented as number (\%).

tients wore protective clothing. According to a study by Han et al. [18], the attitude toward radiation safety management was reported to have a higher attitude score toward radiation safety management as the guardians, and dental hygienists wore lead protective clothing. In the study of Jang et al. [19], it was also reported that the higher the self-management attitude toward radiation exposure during work of dental hygienists, the higher the quality of life.

Table 4 shows dental radiation safety management practices. When conducting or receiving a performance test of an apron for radiation protection, the highest value was $3.68 \pm 1.078$, and the second highest was $3.17 \pm 1.201$ after maintaining an appropriate distance from the radiation source and the patient during irradiation. The lowest value was $1.74 \pm 1.182$ after having the guardian wear protective clothing as a patient assistant during radiation irradiation, and $1.59 \pm 0.915$ after adjusting the X-ray dose according to conditions such as age, imaging site, and film size.

According to the study by Jun and Han [12], the radiation safety management behavior for the dental hygienist was higher than the radiation safety management behavior for the dental hygienist himself. Knowledge appeared to be the most important. The disinfection of dental radiography equipment is shown in Table 5. Disinfection of X-ray tube head once a month was the highest at 50 people $(33.1 \%)$, digital sensor disinfection once a day was the highest at 63 people (41.7\%), and imaging aids (XCP, etc.) Disinfection once a day was the highest with 55 people $(36.4 \%)$, and disinfection of protective equipment (lead skirt, etc.) once a day was the highest with 45 people $(29.8 \%)$. Also, disinfection of film cassette once a day was found to be the highest at 58 people (38.4\%), disinfection of once a day of panorama shooting table was the highest at 58 people (38.4\%), and disinfection of once a day of cephalopod was highest at 58 people (38.4\%). This was the highest with 55 $(36.4 \%)$, and the highest number of 52 people (34.4\%) was that the back seat and stool were disinfected for each patient. 'I do not wear gloves at all during dental radiography' was the highest with 52 people (34.5\%), 'I always wear a mask for dental radiography' was the highest with 56 people (37.1\%), and 'I wear a apron and film holding device sterilization or disinfection occasionally' was the highest with 68 people (45.0\%). The method of sterilizing dental radiography equipment was the highest with alcohol sterilizing 97 people (64.2\%) and 'Keep the abductor in the studio' was the highest with 87 people (57.6\%) (Table 6).

According to Lee [20]'s study, it is reported that knowledge about dental radiation safety management was affected by factors such as attitude and behavior, and behavior about dental radiation safety management was affected by knowledge and attitude. In order to raise the level of knowledge and attitude that affects dental radiation safety management behavior, appropriate education for dental medical institutions will be required. In Korea, radiation workers must complete medical radiation safety management education within one year from the date of appointment of the person in charge. Due to spatial limitations, customized education cannot be implemented by region, and it is difficult to conduct radiation safety education for workers at front-line medical institutions due to the lack of educational content necessary for medical radiation safety management education, except for large hospitals [21]. Also, because it can provide professional features, it will help you in training and help you improve your skills.

\section{Conclusion}

In this study, the following conclusions were obtained by 
studying the knowledge, attitude, and behavior of dental hygienists about radiation safety management and the characteristics of disinfection during dental radiography.

1. As for the age of the subjects, 44 people (29.1\%) were aged $20-25,39$ people $(25.8 \%)$ were aged $26-30$, and 40 people (26.5\%) were aged 31-33. By sex, 125 people (82.8\%) were female, and the highest number of workplaces was a dental clinic with 112 people $(74.2 \%)$. As for the number of years of service, those with less than 1 year and those who had 11-15 years had the highest number of 56 people (37.1\%).

2 . Dental radiation safety management knowledge showed the highest score of $3.58 \pm 1.035$ in 'The occupational exposure dose regulations cannot exceed $20 \mathrm{mSv}$ per year on average for 5 years'. Individual exposure can be measured' was the lowest at $1.56 \pm 0.869$.

3. Dental radiation safety management attitude is 'The apron for radiation protection should not be bent or folded'. The highest was $3.27 \pm 1.266$, and the lowest was $1.42 \pm 0.702$, indicating that 'the woman of childbearing potential should check the menstrual cycle or whether she is pregnant before radiation'.

4. Regarding the dental radiation safety management behavior, 'Do or receive a performance test of an apron for radiation protection' was the highest at $3.68 \pm 1.078$, and the lowest was 'X-ray according to conditions such as age, area to be photographed, and film size. Adjust the dose' was shown as $1.59 \pm 0.915$.

5. For the disinfection of dental radiography equipment, the $\mathrm{X}$-ray tube head is disinfected once a month for 50 people (33.1\%), for digital sensors once a day for 63 people (41.7\%), and for imaging aids (XCP, etc.) once a day for 55 people (36.4\%), disinfection of protective equipment (lead skirt, etc.) once a day for 45 people (29.8\%), for film cassette disinfection once a day for 58 people (38.4\%), and for a panoramic camera once a day for disinfection for 58 people (38.4\%). Disinfect the cephalo camera once a day for 55 people (36.4\%), and disinfect the back seat and stool for each patient. 52 people (34.4\%) were investigated.

6. During dental radiography, 52 people (34.5\%) said that they never wore gloves, and 56 people (37.1\%) said they always wore a mask during dental radiography. 68 people (45.0\%) of them wore it, and 97 people (64.2\%) of alcohol sterilized the dental radiography equipment as a disinfection method.

As a result of the above, it is suggested to provide an education program for dental radiation-related workers on a regular basis to raise awareness about radiation safety management knowledge, attitude, and behavior so that they can practice it in medical institutions.

\section{Conflict of Interest}

No potential conflict of interest relevant to this article was reported.

\section{ORCID}

Cheon-Hee Lee, https://orcid.org/0000-0002-3203-8025

Seung Hui Choi, https://orcid.org/0000-0002-5967-1875

\section{References}

1. Im GO, Cho MS, Kang JK, Park JH, Ahn GS, Jang KW, et al. Oral imaging. 3rd ed. Seoul: Komoonsa; 2020.

2. Rhim JD. A comparative analysis of personnel awareness for the safety management rule in diagnosis-purpose radiation [thesis]. [Wonju]: Yonsei University; 2000.

3. Shin GS, Kim YH, Lee BR, Kim SY, Lee GW, Park CS, et al. The actual state and the utilization for dental radiography in Korea. J Radiol Sci Technol 2010;33:109-20.

4. Na HH, Jin HJ, Lee MK. The awareness and performance towards the dental radiation protection behaviors in Busan and Gyeongnam. J Korean Soc Dent Hyg 2014;14:673-80.

5. Yoon JA. A comparative study on radiation safety management knowledge, attitudes and behavior of career dental hygienists and new dental hygienists. J Dent Hyg Sci 2011;11:173-9.

6. Heo J, Choi JH. Radiobiology. Seoul: Shinkwang Pub; 1998:125-9.

7. Han EO. Survey and study on the safety management of radiation: centering on the radiation workers in medical institutions [thesis]. [Seoul]: Ewha Womans University; 2002.

8. Valentin J. The 2007 recommendations of the international commission on radiological protection [Internet]. Orlando: International Commission on Radiological Protection, Elsevier [cited 2014 May 7]. Available from: https://www.icrp.org/publication.asp?id= ICRP\%20Publication\%20103.

9. Korea Ministry of Government Legislation. Korea law information center, Medicallaw [Internet]. Sejong: Korea Ministry of Government Legislation [cited 2014 May 7]. Available from: http:// www.law.go.kr/lsSc.do?menuId=0\&p1 $=\&$ subMenu=1\&nwYn= $1 \&$ section $=\&$ query $=\% \mathrm{EC} \% 83 \% 9 \mathrm{D} \% \mathrm{~EB} \% \mathrm{AA} \% 85 \% \mathrm{EC} \%$ $9 \mathrm{C} \% \mathrm{~A} 4 \% \mathrm{~EB} \% \mathrm{~A} 6 \% \mathrm{AC}+\% \mathrm{~EB} \% \mathrm{~B} 0 \% 8 \mathrm{~F}+\% \mathrm{EC} \% 95 \% 88 \% \mathrm{EC}$ $\% \mathrm{~A} 0 \% 84 \& \mathrm{x}=0 \& \mathrm{y}=0 \#$ liBgcolor0.

10. Jang JH, Hwang SL, Jung HR. The relationship between behavior of radiographic safety control and job stress in dental hygienist. J Dent Hyg Sci 2010;10:265-71.

11. Yun JE. Knowledge and attitude on radiation safety of dental hygienists [thesis]. [Gyeongsan]: Yeungnam University; 2010.

12. Jun SH. Han EO. Analysis of the behavior on the radiation safety management for dental hygienists. J Korean Acad Dent Health 2008;32:363-75.

13. Kim HS. Study on the Knowledge, perception, and behavior about the protection of workers who have risk of radiation-exposure in hospital [thesis]. [Seoul]: Yonsei University; 2001. 
14. Park CS. Oral radiology. Seoul: Komoonsa; 1997:225-36.

15. Ahn HG, Kim HP, Park CS. Basic oral radiology. Seoul: Science Book Center; 1993:50-8.

16. Park IS, Lee KH. A study on the environmental condition and safety in dental radiography room. J Korean Acad Dent Hyg Educ 2004;4: 49-64.

17. Park CS. Applications of digital radiography. J Korean Dent Assoc 2002;40:838-41.

18. Han OS, Woo SH, Kim SY. The knowledge and attitude toward radiation safety management in dental clinic worker. J Korean
Soc Dent Hyg 2014;14:849-57.

19. Jang JH, Lee HN, Lim CH. The effect of occupational exposure on quality of life in dental hygienists. J Korean Soc Dent Hyg 2010;10:715-25

20. Lee KH. A study on radiation safety management by dental hygienist [thesis]. [Seoul]: Dankook University; 2004.

21. Kang SH, Gil JW, Lee BY, Lee HG, Lee SS. A study on the current status and awareness improvement of radiation safety management systems in dentistry in Korea. Pub Health Wkly Rep 2020; 13:1027-36. 